\title{
Pre-service Science Teachers' Impressions on The Implementation of Small-Scale Chemistry Practicum
}

\author{
Muhamad Imaduddin ${ }^{1} *$, Supawan Tantayanon ${ }^{2}$, Fitria Fatichatul Hidayah ${ }^{3}$, \\ Anggun Zuhaida ${ }^{4}$ \\ ${ }^{1}$ Institut Agama Islam Negeri Kudus, Indonesia \\ ${ }^{2}$ Department of Chemistry, Faculty of Science, Chulalongkorn University, Thailand \\ ${ }^{3}$ Universitas Muhammadiyah Semarang, Indonesia \\ ${ }^{4}$ Institut Agama Islam Negeri Salatiga, Indonesia \\ *Correspondence: imad@iainkudus.ac.id
}

\begin{tabular}{ll}
\hline & Abstract \\
\hline Keywords: & This study aims to describe the implementation of the small-scale chemistry approach \\
Small-scale & in the practicum, as well as to show various Pre-service Science Teachers" \\
chemistry & impressions. This research is action research involving 69 Pre-service Science \\
Pre-service science & Teachers (PSTs), 15 males and 54 females. Collecting data using documentation \\
teachers & techniques at each stage of practicum activities, as well as reflection sheets. The \\
Impression & results of the documentation are presented and analyzed using narrative descriptions, \\
& while the results of the reflections from the PSTs are coded and grouped into (1) the \\
& most memorable experiment, (2) positive impressions, and (3) negative impressions. \\
& The practicum covers five topics, namely (1) separation of the mixture (filtration), (2) \\
& reaction rate, (3) oxidation and reduction reactions (electrolysis), (4) heat transfer \\
& (calorimeter), and (5) acid-base solution. The practicum that gave the most impressive \\
& was the practicum on acid-base solutions (41.2\%), while the one that got the least \\
impressive was the practicum on calorimeters (4.4\%). Many positive impressions that & appear in practicum activities are "low-cost", "colorful", "easy to carry", "hard to \\
break", "material savings", and "more understandable". The most negative \\
impressions that appear in the series of implementation activities are "limited tools", \\
"too small-scale tools" and "inaccuracy". The result of the teacher's reflection finally \\
considers the impression of "limited tools", "material limitation", and "too simple" to \\
be a consideration in developing further practicum activities with the SSC approach.
\end{tabular}

To cite this article:

Imaduddin, M., Tantayanon, S., Hidayah, F. F., \& Zuhaida, A. (2020). Pre-service science teachers' impressions on the implementation of small-scale chemistry practicum. Thabiea : Journal of Natural Science Teaching, Vol. 3(2), 162-174.

\section{Introduction}

In the science curriculum, chemistry practicum activities are a crucial part of both the high school and college levels. Direct experience gained in the practicum process can construct concepts (Bradley, 1999; Lunetta et al., 2007), foster a positive attitude and interest in chemistry, and improve communication and collaboration skills (Hofstein \& Lunetta, 2004). There are still many obstacles to implementing practicum activities. This includes constraints on the budget for implementation, inadequate laboratory conditions, limited equipment and chemicals, absence of laboratory personnel, problems with the duration of activities, low quality of educators, and poor laboratory management (Bell \& Bradley, 2012; Bradley, 2001; Tsaparlis, 2016). This condition has also occurred in several educational institutions including science teacher training programs, especially those that are still newly 
established and are in the process of structuring their infrastructure. Previous research has shown how important it is to improve laboratory skills for pre-service science teachers (PSTs) (Imaduddin \& Hidayah, 2019; Zuhaida \& Imaduddin, 2019).

Various solutions to these problems have been offered, such as the implementation of demonstration learning, learning with virtual laboratories, films, videos, and illustrations on the blackboard. However, hands-on activities will still be irreplaceable as a laboratory learning solution (Bradley, 1999). Chemistry practicum is not always expensive, instead, it should be able to present a variety of hands-on strategies that are low-cost and sustainable (Bradley et al., 1998; Musar, 1993; Sane, 1999). One of the compatible strategies is a smallscale chemistry approach in practicum activities.

Small-Scale Chemistry (SSC) is an approach that minimizes laboratory work activities than conventional laboratory activities (macro scale). This approach reduces drastically (up to 1000 times) the use of chemicals (Mamlok-Naaman \& Barnea, 2012), as well as sets the existing lab equipment to a smaller size and is made of plastic (Tesfamariam et al., 2017). SSC is a chemical experiment conducted on a scale that is reduced through the use of a small amount of chemical, and often uses simple equipment with a shift from glass to plastic material (Skinner, 1999). 25-100 milligrams of solids and 100-200 microliters of liquid can be used to carry out chemical work without reducing quality and standards in both education and industry (Singh et al., 1999). Implementing this approach can save costs and work duration, increase laboratory work safety, and be more environmentally friendly (Bradley et al., 1998; Mohamed et al., 2012; Singh et al., 1999; Skinner, 1999; Zakaria et al., 2012). SSC is an innovation of effective teaching approaches and tools. This concept is related to the drastic reduction in the number of chemicals in laboratory activities, the use of miniature labware, and the manipulation of safe and easy work procedures. The accuracy of the experiment is not a problem, and the teacher can also implement it as a new practical activity design (Abdullah et al., 2009). SSC provides hands-on classroom experiences. SSC can improve the quality of teaching chemistry through an environmentally friendly approach (Abdullah et al., 2007).

SSC was originally popularized in the organic chemistry laboratory at Bowdoin College, Maine. The scope of research extends to general, analytical, inorganic, and environmental chemistry. In 1992-1993, The National Microscale Chemistry Center was started at Merrimack College as the first center to officially offer SSC training activities for teachers and chemists (Singh et al., 1999). In Indonesia, presumably, the SSC approach in teaching science, especially chemistry is still not widely known by middle school and university students and is rarely applied by teachers (Listyarini et al., 2019). As one of the study programs in progress with its infrastructure, the training program of PSTs at Institut Agama Islam Negeri (IAIN) Kudus has obstacles in the implementation of basic chemistry practicum activities. The implementation of chemical practicum activities is still constrained due to the special laboratory space, the limited availability of tools, limited chemical materials, and the absence of laboratory assistants. Seeing the various advantages of this approach, SSC is expected to be a solution in the implementation of practicum activities for PSTs.

Some research activities focus on developing procedures for using micro-scale kits. Worley modified small-scale tools as a substitute for existing laboratory tools to make practicum activities easier, safer, and activity procedures acceptable to teachers (Worley \& 
Kingdom, 2018). Another study manipulated the workings of practicums so that students could visualize the dissolution process, ion mobility, and precipitation at the micro-scale level. The characteristic of this activity is the minimal use of materials so that the waste is not abundant (Worley et al., 2019). As the start of the process of developing laboratory activities, it will be interesting to first look at the impressions that PSTs have on activity design. Therefore, as an effort to overcome the real obstacles faced by the science education study program at IAIN Kudus, the implementation of small scale chemistry in practicum activities is designed with a series of activities. This research aims to describe how the implementation of the SSC approach in lectures for PSTs, as well as to reveal how the various impressions that appear after practicum activities with the SSC approach.

\section{Method}

This research is action research that aims to solve the problem of the absence of laboratory space, as well as tools and materials for chemistry lab work in the training programs of PSTs. Action research is a powerful and impressive tool for improving quality at the local level (Cohen et al., 2007). This action research leads to an understanding of what is going on, so it is descriptive research (Sagor, 2005), in which the research cycle uses four stages as shown in Figure 1.

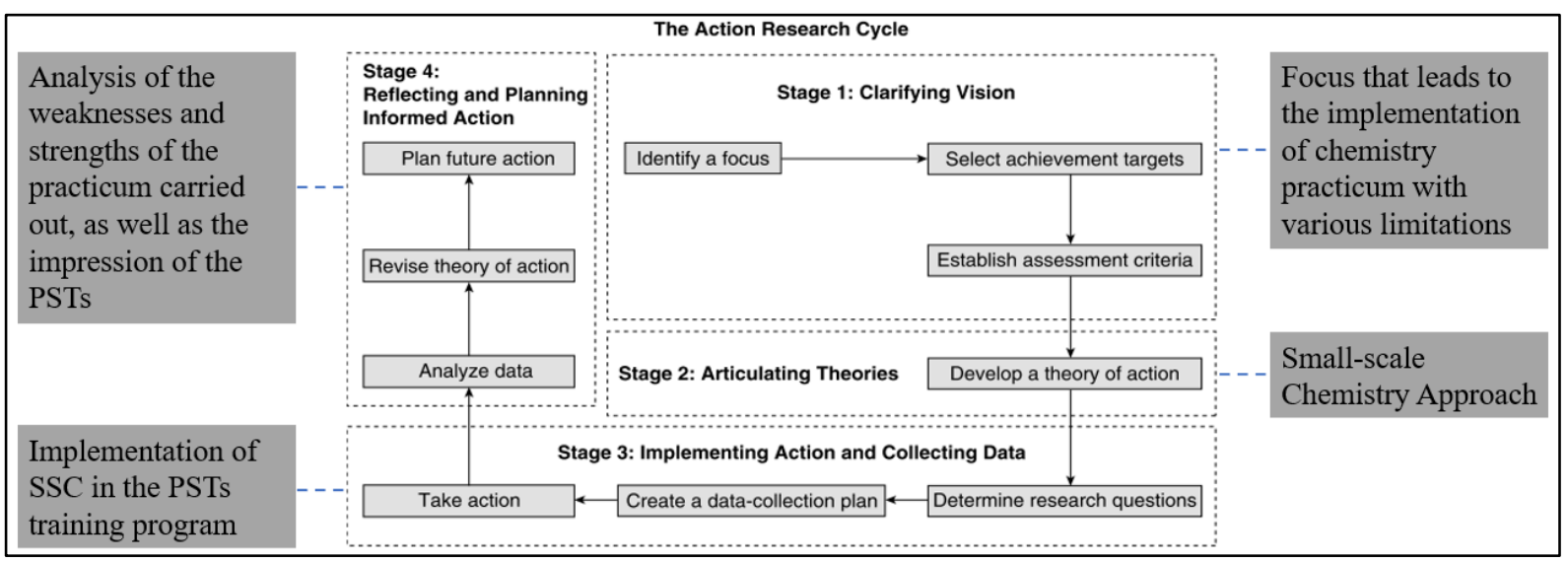

Figure 1. The modified action research cycle of Sagor (2005)

Practicum implementation is based on the skill needs of PSTs based on chemistry topics that will be taught by them at the high school level. The series of practicum activities using the SSC approach was carried out on the topics (1) separation of the mixture (filtration), (2) reaction rate, (3) oxidation and reduction reactions (electrolysis), (4) heat transfer (calorimeter), and (5) acid-base solution.

This study involved 69 PSTs consisting of 15 males and 54 females. This activity was carried out in the Basic Chemistry Practicum course, which was in the second year of the program. These PSTs had minimal experience with previous laboratory activities. This is indicated by 31 students who stated that the laboratory owned by the school at the previous level was "Rare" (ie used at the end of the semester) and "Very Rare" (ie only about once or twice when they were in high school students) in terms of its use. 
Collecting data using documentation techniques at each stage of practicum activities, as well as reflection sheets. Documentation includes spatial conditions and stages in the practicum process, while reflection is directed to reveal the impression of the activity, as well as how the reflection of PSTs on the advantages and disadvantages of practicum activities. Through an open reflection sheet, PSTs were allowed to freely write them down. The results of the documentation are presented and analyzed using narrative descriptions, while the results of the reflections from the PSTs are coded and grouped into (1) the most memorable experiment, (2) positive impressions, and (3) negative impressions. Furthermore, the reflection presentation is analyzed for its coding frequency using QDA Miner Lite so that the word cloud and bar chart are obtained.

\section{Results and Discussion}

This chemistry lab activity has begun with the design and assembly of a small-scale chemistry kit. In the process of designing a kit, the costs for the tools and materials have been taken into account, the size of the tools used, and the number of materials used. The kit arrangement in this research activity included 11 SSC kit boxes which were used for 11 groups of PSTs. This set of kits is used for five practical activities. The tools are arranged in box packages as shown in Figure 2. The component details of the prepared kit boxes are shown in Table 1. The boxes are used in practicum activities with the ease of being moved and stored.

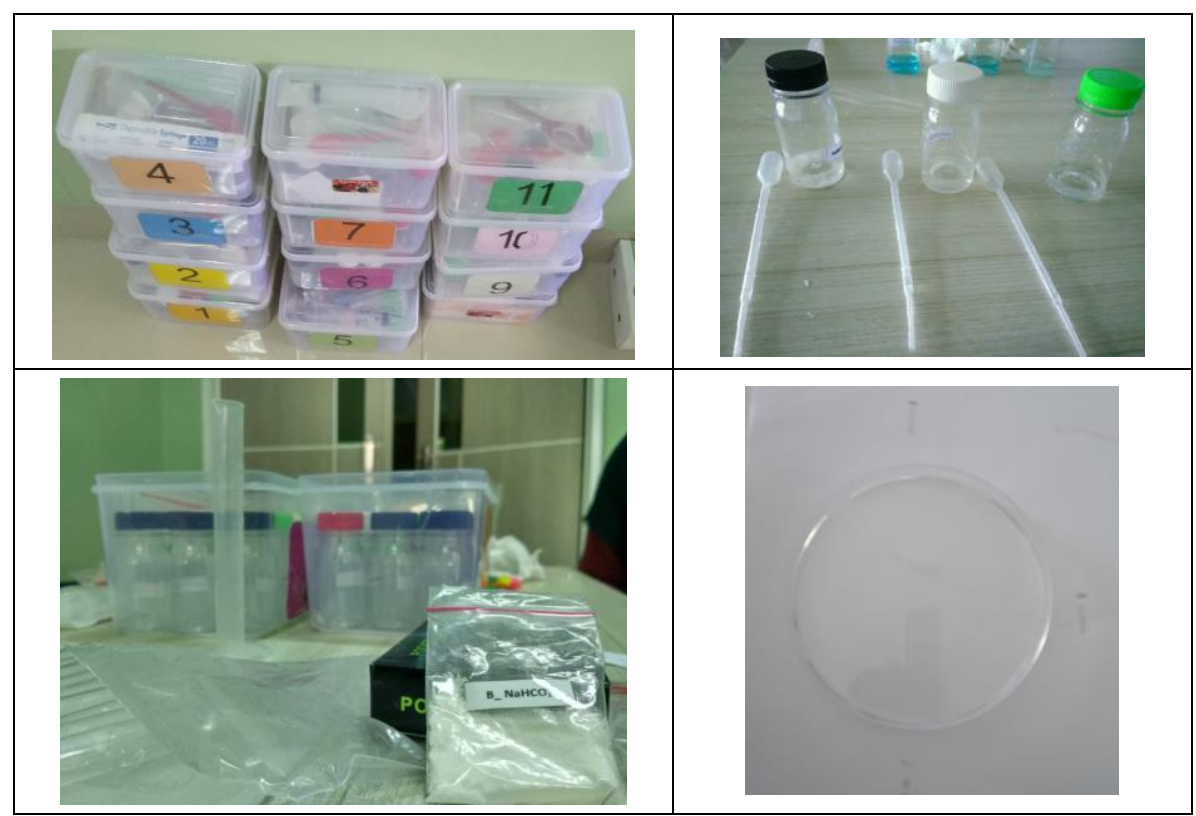

Figure 2. Several packages of "small-scale chemistry boxes" with some of the tools and materials 
Table 1. Components in the Small Scale Chemistry box

\begin{tabular}{|c|c|c|}
\hline No & Category & Specifications \\
\hline 1 & $\begin{array}{l}\text { Containers for } \\
\text { material preparation }\end{array}$ & $\begin{array}{l}\text { 1) Plastic bottle } 50 \mathrm{ml} \\
\text { 2) Plastic mini cup (pot) } 10 \mathrm{cc}\end{array}$ \\
\hline 2 & $\begin{array}{l}\text { Tools for moving } \\
\text { materials }\end{array}$ & $\begin{array}{l}\text { 1) Small plastic spoon } \\
\text { 2) Drop Pipette for cupcakes ( } \operatorname{size} 4 \mathrm{ml} \text { ) } \\
\text { 3) Syringe } 20 \mathrm{ml} \\
\text { 4) Mini funnel (high: } 3.9 \mathrm{~cm} \text {; funnel diameter: } 3.1 \mathrm{~cm} \text {, hole diameter: } 0.6 \mathrm{~cm} \text { ) }\end{array}$ \\
\hline 3 & $\begin{array}{l}\text { Containers } \\
\text { reacting } \\
\text { ingredients }\end{array}$ & $\begin{array}{l}\text { 1) Plastic bottle } 50 \mathrm{ml} \\
\text { 2) Test tube }(12 \times 75 \mathrm{~mm}) \\
\text { 3) Plastic petri dish }(90 \times 15 \mathrm{~mm}) \\
\text { 4) } 96 \text {-Well microplate }(85.4 \times 127.6 \mathrm{~mm})\end{array}$ \\
\hline 4 & Measuring tools & $\begin{array}{l}\text { 1) Measuring pipette } 1 \mathrm{ml}, 3 \mathrm{ml}, 5 \mathrm{ml} \\
\text { 2) Measuring cylinder } 10 \mathrm{ml} \\
\text { 3) Mini digital scale balance (capacity: } 500 \text { gram \& accuracy: } 0.01 \text { gram }) \\
\text { 4) Mini digital Thermometer }\left(45 \mathrm{~mm} \times 28.6 \mathrm{~mm} \times 15.2 \mathrm{~mm} \text {; accuracy: }-50^{\circ} \mathrm{C} \sim 110^{\circ} \mathrm{C} \text { ) }\right.\end{array}$ \\
\hline
\end{tabular}

In this study, the experiment was set to a minimum in using solid or liquid chemicals. A significant characteristic of activities with the SSC approach is the use of a minimum amount of resources so that the resulting waste is small (Worley et al., 2019). This is in line with other studies that manipulate procedures to allow students to visualize dissolution processes, ion mobility, and precipitation at the micro-scale level (Worley et al., 2019). Other studies also show that small lab kits provide solutions for chemical practices to run more effectively. Student groups can be downsized into two people per group to increase direct involvement (Zakaria et al., 2012). In this research, students in one group consisted of three to four PSTs. Classroom sets are made as effective as possible for the movement and mobility of PSTs in carrying out a series of practicum activities. Mobility is needed to take materials and tools that are used together, as well as provide classroom comfort so that it doesn't feel stuffy and air circulation is smooth. The classroom layout is set in a circle as shown in Figure 3.
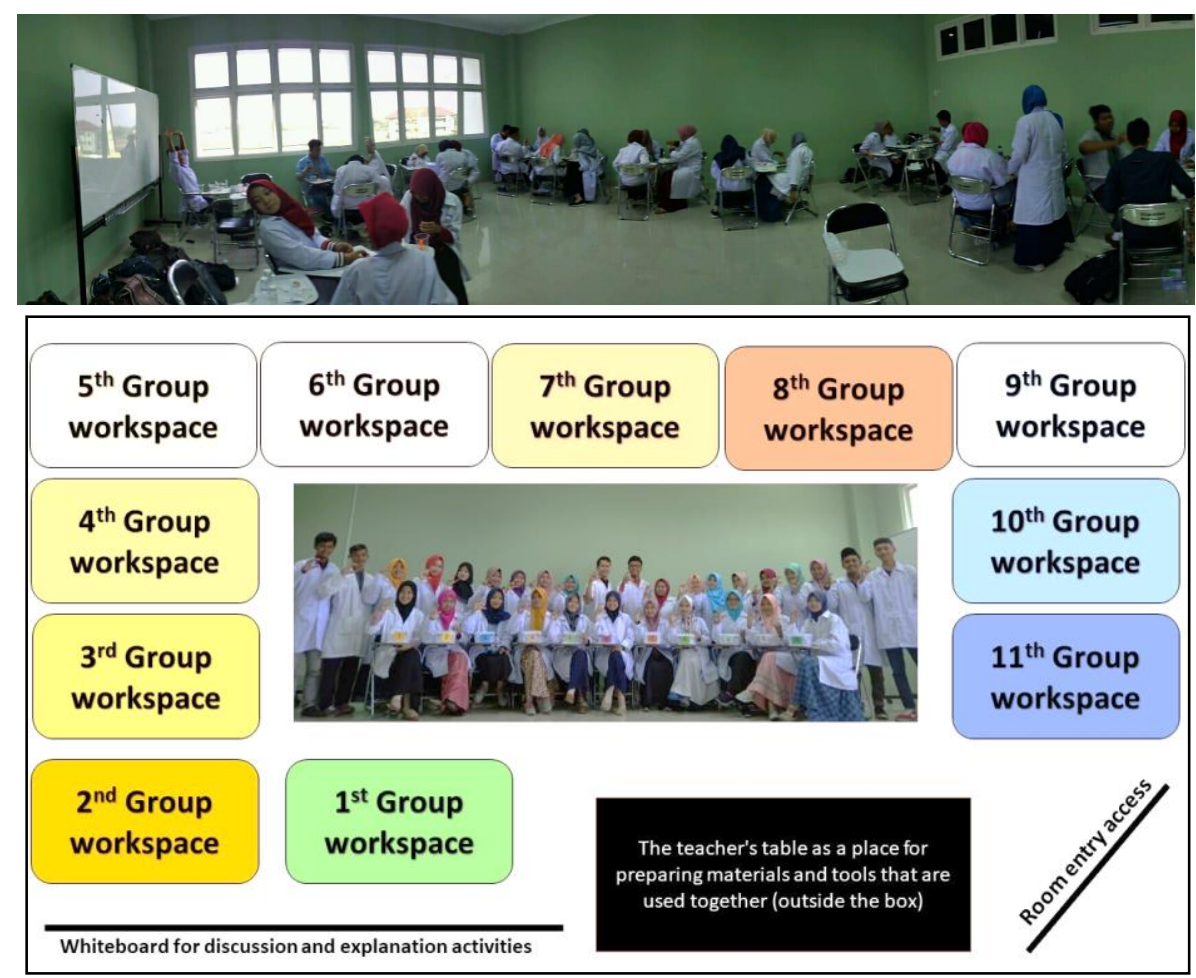

Figure 3. Classroom setting for small scale chemistry practicum activities 
Table 2. Small-scale chemistry lab activities

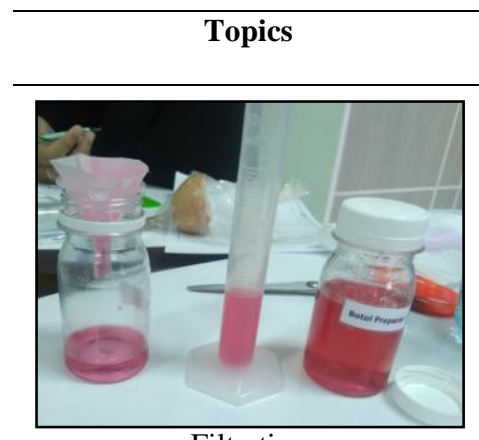

Filtration
The purpose of practicum activities

1) Showing the presence of 1) Mini funnel filtrate and residue, and identifying the most effective filter paper material for the filtration process.

2) Distinguishing the types of homogeneous mixtures and heterogeneous mixtures using a simple filtration method.

3) Identifying the effect of surfactants on the mixture through separation by filtration techniques.
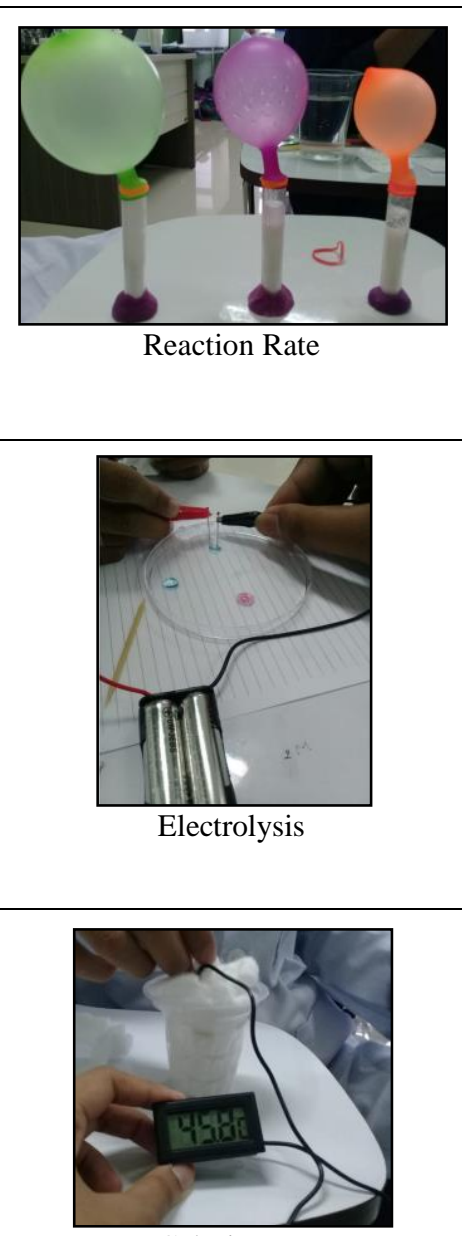
electrolysis of materials,
Reaction Rate

Electrolysis

Calorimeter

1) Analyzing the effect of concentration on reaction rate

2) Analyzing the effect of surface area on reaction rate.

3) Analyzing the effect of temperature on the reaction 5 rate

1) Showing the existence of reduction and oxidation reactions in the electrolysis process

2) Analyzing the course of the reaction in the electrolysis process due to the influence of the concentration and duration of the reaction in the $\mathrm{CuSO}_{4}$ solution

3) Analyzing processes on the other than $\mathrm{CuSO}_{4}$

1) Using a simple calorimeter to determine the heat of the neutralization reaction and the leaching of the material.

2) Investigating and calculating the enthalpy $(\Delta \mathrm{H})$ in the neutralization reaction

3) Investigating and calculating enthalpy $(\Delta \mathrm{H})$ in the dissolving process of $\mathrm{Na}_{2} \mathrm{CO}_{3}$ and $\mathrm{H}_{2} \mathrm{O}$

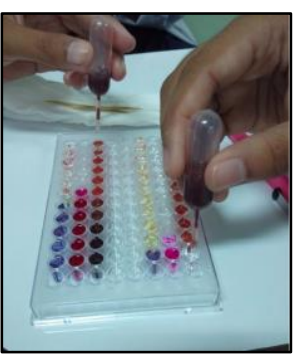

1) Determining the approximate $\mathrm{pH}$ route that can be measured by natural indicators.

2) Performing acid-base titration on a small scale practicum

\section{2) 4 bottles of} preparation

3) measuring cylinder

4) Mixing spoon

5) Pipette

1) Test tube

2) Pipette

3) Measuring cylinder

4) Mini Digital Balance

5) Mini Digital Thermometer

6) Plasticine

7) Rubber

8) Cups from used drinks

1) Petri Dish

2) 9 V Dry Cell Battery

3) Pinch crocodile

4) Cable

5) Safety Pins

6) Preparation bottles

7) Pipette

8) Toothpick

1) Spoon

2) Test tube

3) Measuring cylinder

4) Mini Digital

Balance

5) Mini Digital

Thermometer

6) Cotton

7) Plastic cup
1) Sample [mixture 1] for control

2) Sample [mixture 2]: milk or cooking oil (choose one); granulated sugar solution or syrup (choose one).

3) Paper materials consisting of: [1] Paper, [2] Tissue, [3] Lab filter paper.

4) Cooking oil

5) Powder detergent, liquid soap, and salt for surfactant experiments

1) Baking Soda $\left(\mathrm{NaHCO}_{3}\right)$.

2) Eggshells (finely ground and coarsely ground).

3) $\mathrm{CH}_{3} \mathrm{COOH}$ solution with a concentration of $25 \%, 10 \%$, and $5 \%$.

4) Small balloons of the same size and the same brand.

$\begin{array}{ll}\text { 1) } & \text { Soda Ash / Soda Ash / } \\ \mathrm{Na}_{2} \mathrm{CO}_{3} & \\ \text { 2) } & \mathrm{CuSO}_{4} \text { solution } 1 \mathrm{M} \\ \text { 3) } & \text { Sodium Carbonate } \\ & \left(\mathrm{Na}_{2} \mathrm{CO}_{3}\right) \text { Solution }\end{array}$

$\mathrm{HCl} 0.2 \mathrm{~N}$

$\mathrm{NaOH} 0.2 \mathrm{~N}$

$\mathrm{Na}_{2} \mathrm{CO}_{3} 0.2 \mathrm{~N}$

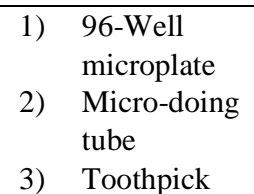

1) $\mathrm{pH} \mathrm{Stick}$

2) Phenolphthalein (1\%).

3) Natural indicators made from Carrot Extract, Red Cabbage Extract, Shoe Flower Extract, Teak Leaf Extract, Turmeric Extract.

4) Tissue

5) vinegar $0.01 \mathrm{M}$

6) $\mathrm{HCl}$ solution $0.01 \mathrm{M}$

7) $\mathrm{NaOH}$ solution $0.01 \mathrm{M}$ 
The SSC approach can overcome various challenges faced by teachers when preparing practicum plans including conditions of lack of equipment and chemicals, absence of laboratory assistants, absence of laboratory space, lack of time, and lack of teacher confidence (Bradley et al., 1998). The SSC kit is used in classrooms with limited access to water and usually functions as a conventional classroom $(8.56 \mathrm{~m} \times 6.85 \mathrm{~m})$. An overview of the activities with the small scale chemistry kit is shown in Figure 2. Class sets were made with attention to the group workspace for optimal. The details for the practicum activities that are implemented are shown in Table 2.

Based on the five practicum activities that are implemented, then it is analyzed how the impression of PSTs on a series of practical activities. PSTs were asked to show the most memorable practicum. Figure 4. shows that each practicum has an impression for PSTs, even though some PSTs do not show specifically in any of the practicums that are implemented. The practicum that gave the most impressive was the practicum on acid-base solutions $(41.2 \%)$, while the one that got the least impressive was the practicum on calorimeters $(4.4 \%)$. The acid-base solution practicum gets a deep impression because it has a long duration of activity series compared to other practicums, and also gives colorful results. The colors produced in the $\mathrm{pH}$ identification process are attractive to PSTs.

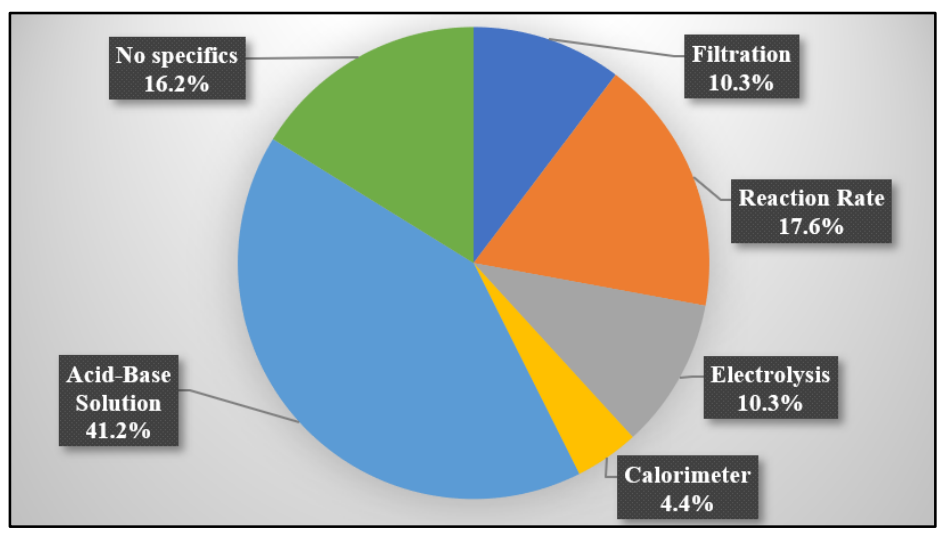

Figure 4. The distribution of the most memorable practicum topics for PSTs $(N=69)$

Figure 5. shows that the most positive impressions arising from PSTs in a series of practicum activities with the SSC approach are "low-cost" and "colorful". The small-scale practicum allows a reduction in financing up to $82 \%$ (Abdullah et al., 2013). In this research, the need for tools and materials used for five activities and 11 groups in each class (two study groups) is estimated to be under IDR 5,000,000. The impression of "material savings" also shows how PSTs' awareness that practicum with the SSC approach saves material needs. The quality of learning can be improved and the number of chemicals can be reduced 10 times or even lower in some experiments (Zakaria et al., 2012). In line with this, the practicum design that has been done can be recommended for practicum activities for educational institutions that do have limited facilities and infrastructure. Another aspect of the impression, namely "colorful", is related to the experience of PSTs working on activities to determine the properties of acid-base solutions using various indicators. The results obtained from the experiment showed a diversity of colors. 


\section{More Understandable New Experience Accuracy Patience challenging Happy}

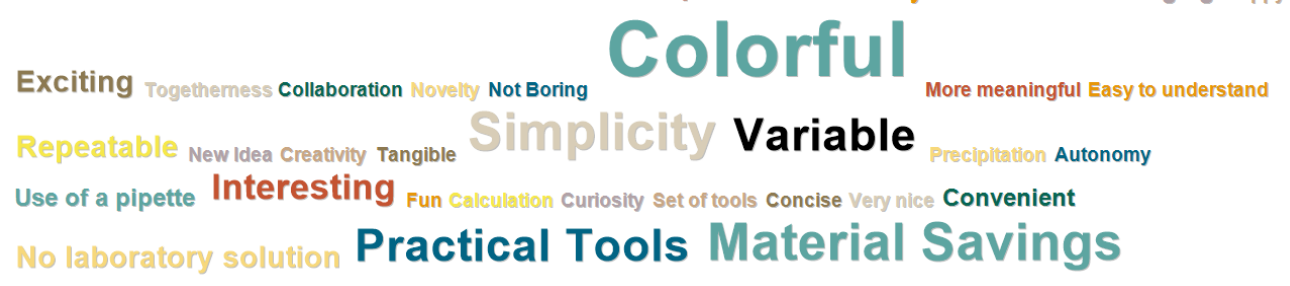

Waste minimization Tool limitation solution Easy to carry

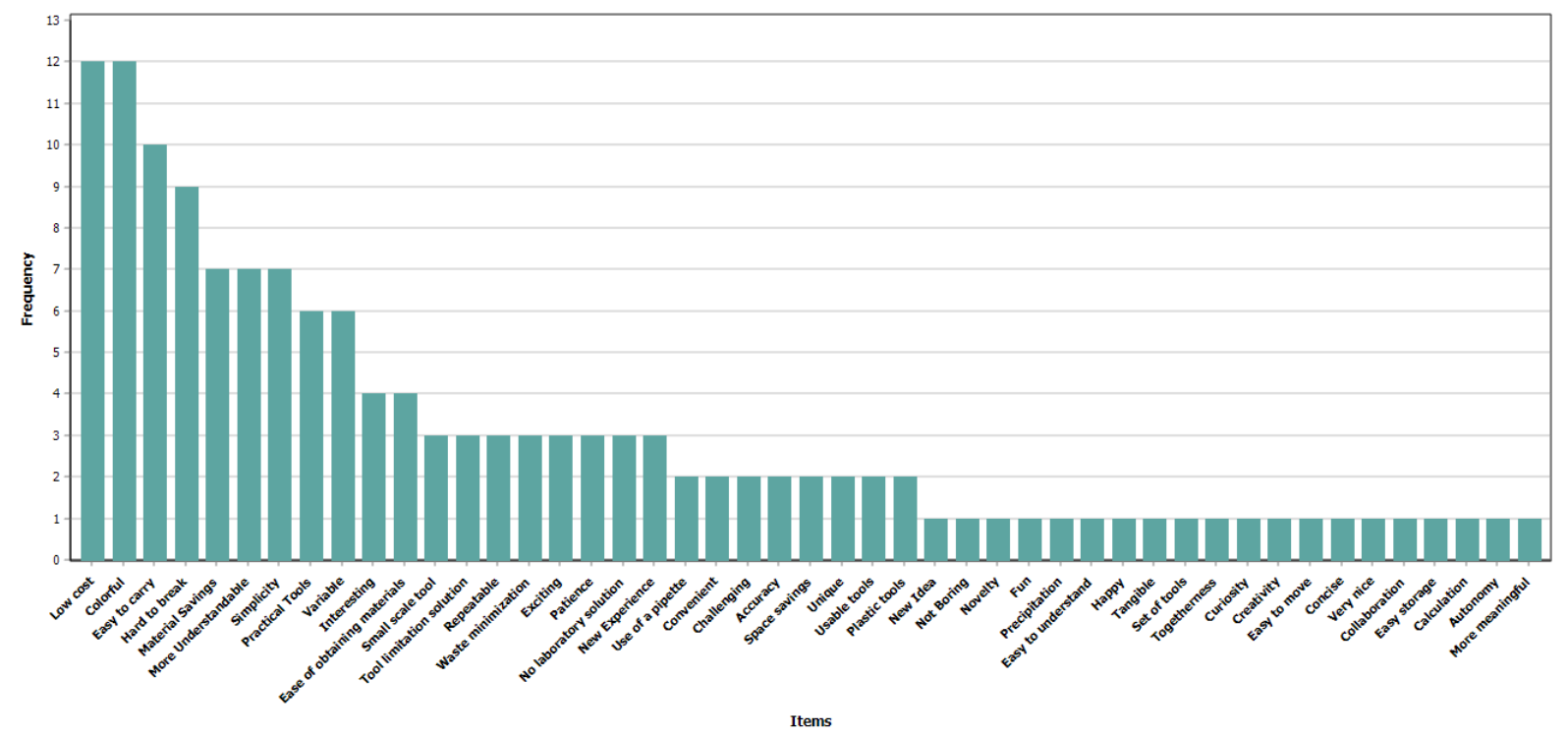

Figure 5. Distribution of PSTs' positive impressions in a small-scale chemistry lab $(N=69$ PSTs)

On the aspect of the tool, PSTs show an impression of "Easy to carry" and "Hard to break" which means that the kit they use is easy to carry around and not easily damaged. This is in line with the study (Zakaria et al., 2012) which stated the responds and the results of using small-scale kits in organic chemistry lab work. Hanson also introduced a microscale kit to students to assess their feasibility when implemented in all chemical activities. About $79 \%$ $(\mathrm{N}=110)$ of the sample agreed that the kit introduced was feasible, fun, and easy to use (Hanson, 2014). This is in line with the impression of "Practical Tools", "Fun", and "Convenient". Besides that, the impression of "More Understandable" also dominates in this activity. The various impressions that exist are in line with the various advantages of implementing practicum with the SSC approach including saving costs and time, increasing safety, being easy to use and environmentally friendly, instilling ethics of resource conservation, increasing students' understanding of scientific concepts, maintaining student interest in the eye lessons, involve students directly, provide individual learning experiences, and provide easy and fun experiments (Abdullah et al., 2009; Bradley, 1999; Kelkar et al., 
2001; Mattson \& Anderson, 2011; Mayo et al., 2011; Poppe et al., 2010; Singh et al., 1999; Skinner, 1999; Tallmadge et al., 2004; Vermaak \& Bradley, 2003; Zakaria et al., 2012).

Difficult to use small tools Failure

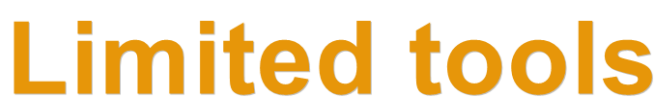

Limited space Lack of concentration Repeating for failure Complicated Difficult

Less meaningful

Work step error Confusion Incautious

Dosage mismatch Difficult to measure Work accident Shocking reaction

Difficulty in tool assembly Material limitations

Lack of accuracy of the tool

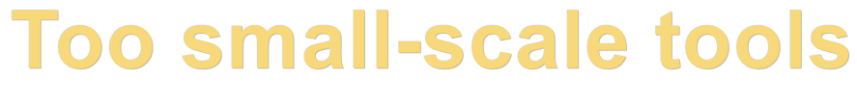

Unstandardized tools Limited duration of practicum Easy to lose tool

Tearable plastic

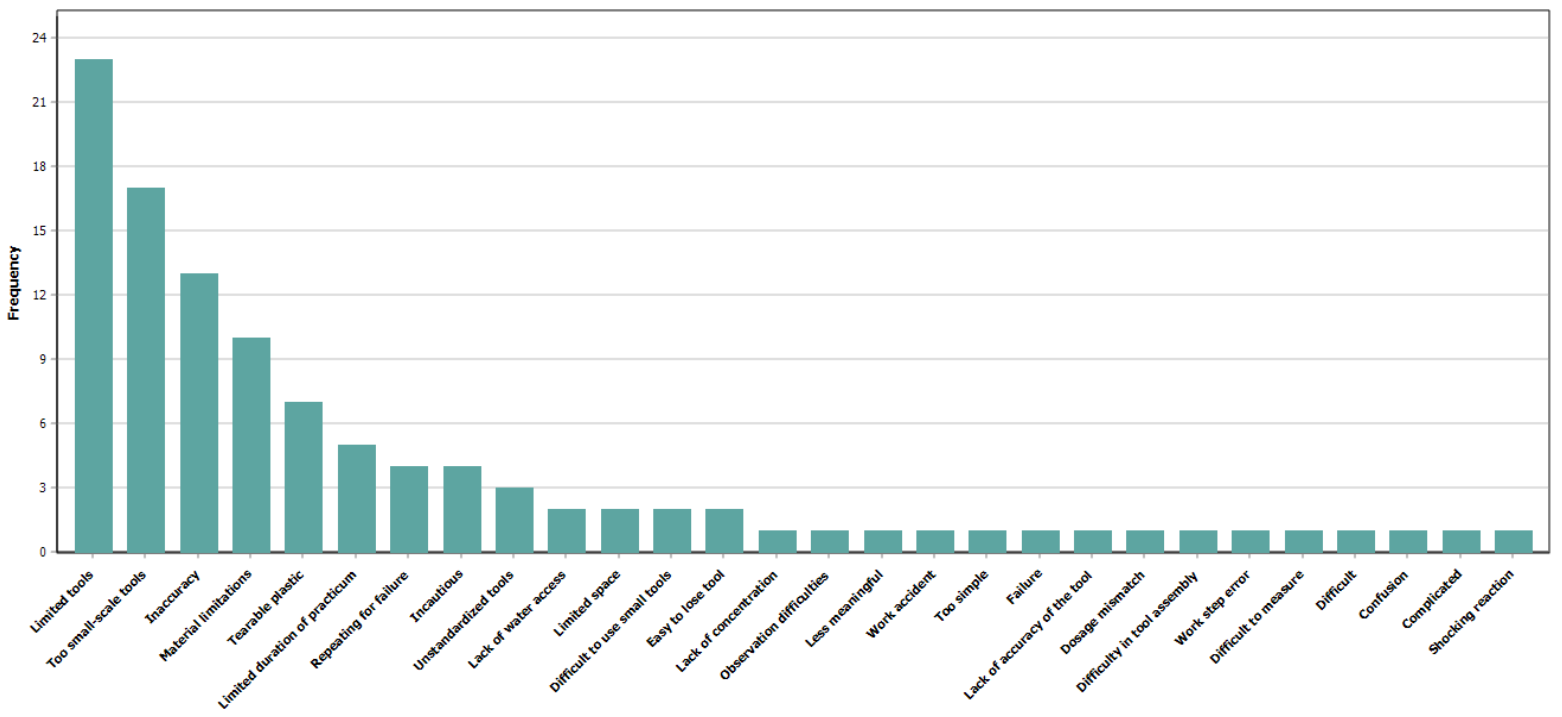

Figure 6. Distribution of PSTs' negative impressions in a small-scale chemistry lab (N=69

PSTs)

The SSC approach can improve students' understanding of chemical concepts despite some challenges in operating small-scale equipment, collecting quantitative data, and maintaining classroom discipline (Tesfamariam et al., 2017). Some negative impressions are shown in Figure 6. The most negative impressions that arise are that of "Limited tools", "Too small-scale tools", and "Inaccuracy". Abdullah et al. (2009, 2013) showed the various constraints in implementing small-scale kits that include difficulties in handling equipment that is too small to fall off and be lost, difficulties in washing equipment, and low precision obtained for experiments involving volume and mass measurement. However, this condition trains PSTs to work more carefully and patiently as shown in the positive impression aspect. This approach encourages students to work on experiments with caution and patience (Abdullah et al., 2007). 
Table 3. Educator's reflections in implementing the SSC approach

\begin{tabular}{|c|c|c|c|c|}
\hline \multirow[t]{2}{*}{ No } & \multirow[t]{2}{*}{ Topics } & \multicolumn{3}{|c|}{ Educator's reflection } \\
\hline & & Aspects of Student & Aspects of Implementation & $\begin{array}{c}\text { Aspects of Tools and } \\
\text { Materials }\end{array}$ \\
\hline 1 & Filtration & $\begin{array}{l}\text { Students are still not familiar } \\
\text { with the process of distributing } \\
\text { work per team member, as well } \\
\text { as plotting work at each stage } \\
\text { of the activity. }\end{array}$ & $\begin{array}{l}\text { The duration of implementation } \\
\text { cannot be streamlined because } \\
\text { the division of teamwork } \\
\text { cannot be optimized. } \\
\text { The filtration process takes } \\
\text { quite a long time, however, } \\
\text { during the process, not many } \\
\text { student teams optimize it by } \\
\text { carrying out work step jumps, } \\
\text { even though it can be done. }\end{array}$ & $\begin{array}{l}\text { Tools and materials can be } \\
\text { obtained easily. The main } \\
\text { ingredients used are kitchen } \\
\text { ingredients, such as oil, milk, } \\
\text { sugar, and salt. }\end{array}$ \\
\hline 2 & $\begin{array}{l}\text { Reaction } \\
\text { Rate }\end{array}$ & $\begin{array}{l}\text { The distribution for student } \\
\text { work already looks tidier than } \\
\text { the previous practicum } \\
\text { activities. }\end{array}$ & $\begin{array}{l}\text { The duration of the practicum is } \\
\text { short and more efficient than } \\
\text { previous activities }\end{array}$ & $\begin{array}{l}\text { Tools and materials can be } \\
\text { obtained easily, the main } \\
\text { ingredients used are vinegar, } \\
\text { baking soda, and eggshells. }\end{array}$ \\
\hline 3 & Electrolysis & $\begin{array}{l}\text { Students can carry out this } \\
\text { practicum many times and } \\
\text { alternately. }\end{array}$ & $\begin{array}{l}\text { Practicum duration is very short and } \\
\text { efficient to show the factors that } \\
\text { affect the electrolysis process. }\end{array}$ & $\begin{array}{l}\text { It is necessary to prepare } \\
\mathrm{CuSO} 4 \text { with several types of } \\
\text { concentrations, and other } \\
\text { solution variants are still } \\
\text { needed. }\end{array}$ \\
\hline 4 & Calorimeter & $\begin{array}{l}\text { Students are easy to follow the } \\
\text { procedures given for the } \\
\text { preparation of a small-scale } \\
\text { calorimeter. It can be said to be } \\
\text { too easy. }\end{array}$ & $\begin{array}{l}\text { Implementation is short and done } \\
\text { easily by PSTs. }\end{array}$ & $\begin{array}{l}\text { 1) Tools can be set easily and } \\
\text { tend to be too simple. } \\
\text { 2) It is necessary to increase } \\
\text { the variety of materials to } \\
\text { determine the heat of the } \\
\text { reaction, including the } \\
\text { endothermic reaction. }\end{array}$ \\
\hline 5 & $\begin{array}{l}\text { Acid-base } \\
\text { solution }\end{array}$ & $\begin{array}{l}\text { Students do not ever give up on } \\
\text { repeating practicum activities if } \\
\text { there is an error in the color } \\
\text { obtained. }\end{array}$ & $\begin{array}{l}\text { Long duration because the group } \\
\text { repeats several activities due to } \\
\text { inaccuracy and lack of cleanliness } \\
\text { of the tools used. }\end{array}$ & $\begin{array}{l}\text { Tools and materials can be } \\
\text { obtained easily. Before } \\
\text { carrying out the work stages, it } \\
\text { is necessary to ensure that the } \\
\text { condition of the tools used is } \\
\text { really clean. }\end{array}$ \\
\hline
\end{tabular}

Overall, the conditions obtained in the implementation of this series of practicum activities were dominated by various positive impressions from PSTs. On the other hand, negative responses also need to be considered to make improvements to the activities that have been carried out. As a priority scale for improvement of kit design in the future, the negative impression related to the kit, namely "Limited tools", "Material limitation", and "Too simple" is taken into consideration. This is also in line with the results of educators' reflections on chemistry practicum lectures shown in Table 3. Educators are also aware of the conditions of students, the processes that occur in implementation, as well as the conditions of the tools and materials used for small-scale chemistry practicum activities.

Practicum with the SSC approach has implications for practical design that can be implemented in the PSTs training program. Based on the need for tools and materials, as well as budget requirements, the planning of practicum activities can be organized more effectively and efficiently. Minimizing the amount of practicum waste also has positive implications for environmental conservation efforts that are continuously being promoted. 
These results become the starting point for further development of variations in practicum activities that can be implemented in the PSTs training program.

\section{Conclusion}

The implementation of the SSC approach in practicum activities by using a kit designed by considering the scale or size of the tool which includes (1) containers for material preparation; (2) Tools for moving materials; (3) containers for reacting material; (4) Measuring tool. The practicum carried out covers five topics, namely (1) separation of the mixture (filtration), (2) reaction rate, (3) oxidation and reduction reactions (electrolysis), (4) heat transfer (calorimeter), and (5) acid-base solution.

The most impressive practicum was the practicum on acid-base solutions (41.2\%), while the one that received the least impressive was the practicum on calorimeters $(4.4 \%)$. Many positive impressions that appear in practicum activities are "low-cost", "colorful", "easy to carry", "hard to break", "material savings", and "more understandable". The most negative impressions that appear in the series of implementation activities are "limited tools", "too small-scale tools" and "inaccuracy". The result of the educator's reflection finally considers the impression of "limited tools", "material limitation", and "too simple" to be a consideration in developing further practicum activities with the SSC approach.

This research is still limited to the initial implementation of simple practicum designs, as well as reviewing the impressions of prospective teachers on the implementation of the practical design. Further research activities are needed with the aspect of measuring the performance of PSTs. Further research is also needed through the design of various practicum variations, and implementing them in practicum activities that are non-cookbook experiments.

\section{Acknowledgment}

We thank you for the active participation of students who are the first generation of the Science Education study program, IAIN Kudus, Indonesia. Thank you also for the conceptual support, as well as some materials obtained from the workshop activities organized by The Chemical Society of Thailand in collaboration with Bangkok Bank, Thailand.

\section{References}

Abdullah, M., Mohamed, N., \& Ismail, Z. H. (2007). The Effect of Microscale Chemistry Experimentation on Students' Attitude and Motivation towards Chemistry Practical Work. Journal of Science and Mathematics Education in Southeast Asia, 30(2), 44-72.

Abdullah, M., Mohamed, N., \& Ismail, Z. H. (2009). The effect of an individualized laboratory approach through microscale chemistry experimentation on students' understanding of chemistry concepts, motivation and attitudes. Chemistry Education Research and Practice, 10(1), 53-61. https://doi.org/10.1039/b901461f

Abdullah, M., Mohamed, N., \& Ismail, Z. H. (2013). Introducing Microscale Experimentation in Volumetric Analysis for Pre-service Teachers. In M.-H. Chiu, H.-L. Tuan, H.-K. Wu, J.-W. Lin, \& C.-C. Chou (Eds.), Chemistry Education and Sustainability in the Global Age (pp. 311-320). Springer Science+Business Media. https://doi.org/10.1007/978-94007-4860-6_27

Bell, B., \& Bradley, J. (2012). Microchemistry in Africa A Reassessment. African Journal of 
Chemical Education, 2(1), 10-22.

Bradley, J. D. (1999). Hands-on practical chemistry for all. Pure Applied Chemistry, 71(5), $817-823$.

Bradley, J. D. (2001). UNESCO/IUPAC-CTC Global Program in Microchemistry. Pure and Applied Chemistry, 73(7), 1215-1219. https://doi.org/10.1351/pac200173071215

Bradley, J. D., Durbach, S., Bell, B., Mungarulire, J., \& Kimel, H. (1998). Hands-On Practical Chemistry for All: Why and How? Journal of Chemical Education, 75(11), 1406. https://doi.org/10.1021/ed075p1406

Cohen, L., Manion, L., \& Morrison, K. (2007). Research Methods in Education (Sixth Edit). Routledge.

Hanson, R. (2014). Using small scale chemistry equipment for the study of some organic chemistry topics- a case study in an undergraduate class in Ghana. Journal of Education and Practice, 5(18), 59-63.

Hofstein, A., \& Lunetta, V. N. (2004). The Laboratory in Science Education: Foundations for the Twenty-First Century. Science Education, 88(1), 28-54. https://doi.org/10.1002/sce.10106

Imaduddin, M., \& Hidayah, F. F. (2019). Redesigning Laboratories for Pre-service Chemistry Teachers: From Cookbook Experiments to Inquiry-Based Science , Environment , Technology , and Society Approach. Journal of Turkish Science Education, 16(4), 489507. https://doi.org/10.36681/tused.2020.3

Kelkar, S. L., Dhavale, D. D., \& Pol, P. G. (2001). Microscale experiments in chemistryThe need of the new millenium. Resonance, 6(2), 14-22. papers3://publication/uuid/286DB9D5-F423-4737-9D03-DD352A8B855E

Listyarini, R. V., Pamenang, F. D. N., Harta, J., Wijayanti, L. W., Asy’ari, M., \& Lee, W. (2019). The Integration of Green Chemistry Principles into Small Scale Chemistry Practicum for Senior High School Students. Jurnal Pendidikan IPA Indonesia, 8(3), 371-378. https://doi.org/10.15294/jpii.v8i3.19250

Lunetta, V. N., Hofstein, A., \& Clough, M. P. (2007). Learning and teaching in the school science laboratory: An analysis of research, theory, and practice. In S. K. Abell \& N. G. Lederman (Eds.), Handbook of research on science education (pp. 393-441). Erlbaum.

Mamlok-Naaman, R., \& Barnea, N. (2012). Laboratory activities in Israel. Eurasia Journal of Mathematics, Science and Technology Education, 8(1), 49-57. https://doi.org/10.12973/eurasia.2012.816a

Mattson, B., \& Anderson, M. P. (2011). Microscale Gas Chemistry. School Science Review, 92(340), 43-48.

Mayo, D. W., Pike, R. M., \& Forbes, David, C. (2011). Microscale Organic Laboratory: with Multistep and Multiscale Synthesis (Fifth Edit). John Wiley \& Sons, Inc. https://doi.org/10.15713/ins.mmj.3

Mohamed, N., Abdullah, M., \& Ismail, Z. (2012). Ensuring Sustainability through Microscale Chemistry. In R. Sanghi \& V. Singh (Eds.), Green Chemistry for Environmental Redemption. Scivener Publishing.

Musar, A. (1993). Equipment for science education constraints and opportunities (English). In ESP discussion paper series; no. 11.

Poppe, N., Markic, S., \& Eilks, I. (2010). Low cost experimental techniques for science education.

Sagor, R. (2005). The action research guidebook: A four-step process for educators and school teams.

Sane, K. V. (1999). Cost-effective science education in the 21 st century-the role of educational technology. Pure and Applied Chemistry, 71(6), 999-1006. https://doi.org/10.1351/pac199971060999 
Singh, M. M., Szafran, Z., \& Pike, R. M. (1999). Microscale Chemistry and Green Chemistry: Complementary Pedagogies. Journal of Chemical Education, 76(12), 1684.

Skinner, J. (1999). Microscale Chemistry. The Royal Society of Chemistry.

Tallmadge, W., Homan, M., Ruth, C., \& Bilek, G. (2004). A local pollution prevention group collaborates with a high school intermediate unit bringing the benefits of microscale chemistry to high school chemistry labs in the Lake Erie watershed. Chemical Health and Safety, 11(4), 30-33. https://doi.org/10.1016/j.chs.2004.03.011

Tesfamariam, G. M., Lykknes, A., \& Kvittingen, L. (2017). 'Named Small but Doing Great': An Investigation of Small-Scale Chemistry Experimentation for Effective Undergraduate Practical Work. International Journal of Science and Mathematics Education, 15(3), 393-410. https://doi.org/10.1007/s10763-015-9700-z

Tsaparlis, G. (2016). Problems and Solutions in Chemistry Education. Journal of the Turkish Chemical Society Section C: Chemical Education, 1(1), 1-30. https://doi.org/10.1142/7741

Vermaak, I., \& Bradley, J. D. (2003). New Technologies for Effective Science Education Break the Cost Barrier. The British Educational Research Association Annual Conference. http://www.leeds.ac.uk/educol/documents/00003349.htm

Worley, B., Villa, E. M., Gunn, J. M., \& Mattson, B. (2019). Visualizing Dissolution, Ion Mobility, and Precipitation through a Low-Cost, Rapid-Reaction Activity Introducing Microscale Precipitation Chemistry. Journal of Chemical Education, 96(5), 951-954. https://doi.org/10.1021/acs.jchemed.8b00563

Worley, R., \& Kingdom, U. (2018). «In a little you can see a lot»: the impact of practical microscale chemistry on chemical education. Educació Química EduQ, 24, 58-62.

Zakaria, Z., Latip, J., \& Tantayanon, S. (2012). Organic Chemistry Practices for Undergraduates using a Small Lab Kit. Procedia - Social and Behavioral Sciences, 59, 508-514. https://doi.org/10.1016/j.sbspro.2012.09.307

Zuhaida, A., \& Imaduddin, M. (2019). Analisis Level Literasi Laboratorium Kimia Dari Calon Guru Ipa Tahun Pertama. Jurnal Inovasi Pendidikan Kimia, 13(2), 2349 - 2359. 